\title{
CHALLENGING THE ORIGINS OF EUROSCEPTICISM. A HISTORICAL PERSPECTIVE
}

\section{Confrontando los orígenes del euroescepticismo. Una perspectiva histórica}

\author{
BIRTE WASSENBERG \\ Sciences Po Strasbourg, Université de Strasbourg \\ birte.wassenberg@unistra.fr
}

Cómo citar/Citation

Wassenberg, B. (2020)

Challenging the origins of Euroscepticism. A historical perspective.

Historia y Política, 44, 55-79.

doi: https://doi.org/10.18042/hp.44.03

(Reception: 16/11/2019; review: 30/01/2020; acceptance: 12/04/2020; publication: 27/11/2020)

\begin{abstract}
This article challenges two orthodox views of Political Scientists concerning the roots of Euroscepticism. First, it contests that Euroscepticism originated in the UK in 1980s and was primarily advocated by British political parties and the Thatcher government. If defined as an opposition to the federalist European idea, Euroscepticism can indeed be traced back to the very beginning of the European integration process after the Second World War and can then be continuously followed up until today. Second, it questions the so-called end of the permissive consensus in the 1990s and argues that, if public opposition against the EU has indeed amplified since then, this is primarily due to the frequent organization of referenda. Third, whereas Eurosceptic political parties have gained increasing support in the European elections since the 2000s, the possibility of the European people to express their anti-European feelings has already existed since the introduction of European direct elections in 1979. Finally, the article identifies a rather
\end{abstract}


paradoxical link between European elections and Euroscepticism, especially when considering the high degree of abstentions.

\section{Keywords}

Euroscepticism; Anti-Europeanism; resistances to Europe; permissive consensus; history of opposition to Europe.

\section{Resumen}

Este artículo cuestiona la corriente ortodoxa en las ciencias políticas sobre el origen del euroescepticismo. En primer lugar, niega que el euroescepticismo nació en el Reino Unido en la década de 1980 y que fuera promovido principalmente por partidos políticos británicos y el Gobierno de Thatcher. Si se define como oposición a la idea de una Europa federal, el euroescepticismo puede remontarse, en efecto, a los comienzos del proceso de integración europea después de la Segunda Guerra Mundial y puede ser seguido continuamente hasta nuestros días. En segundo lugar, el artículo cuestiona el fin del «consenso permisivo» en la década de 1990, argumentando que, si bien la oposición de la población europea frente a la UE ha aumentado desde entonces, esto se debe más bien a la organización frecuente de referéndums. En tercer lugar, mientras que los partidos políticos euroescépticos han ganado progresivamente su apoyo en las elecciones europeas desde la década del 2000, la posibilidad de que los ciudadanos europeos expresen sus sentimientos antieuropeos ya ha existido desde la introducción de las primeras elecciones europeas por sufragio universal en 1979. Por último, el artículo identifica un vínculo más bien paradójico entre las elecciones europeas y el euroescepticismo, especialmente cuando se considera el elevado índice de abstenciones.

\section{Palabras clave}

Euroescepticismo; antieuropeísmo; resistencias a Europa; consenso permisivo; historia de la oposición a Europa. 


\section{CONTENTS}

I. INTRODUCTION. II. BEYOND BRITISH EUROSCEPTICISM IN THE 1980S: THE DEEP ROOTS OF ANTI-EUROPEANISM. III. A WIDER DEFINITION THAN EUROSCEPTICISM: "RESISTANCES TO EUROPE". IV. QUESTIONING THE LOSS OF THE PERMISSIVE CONSENSUS IN THE 1990S. V. A PARADOXICAL LINK BETWEEN EUROPEAN ELECTIONS AND EUROSCEPTICISM. VI. CONCLUSION. BIBLIOGRAPHY.

\section{INTRODUCTION}

In 2016, the outcome of the "Brexit" referendum has plunged the European Union (EU) into a new crisis which seems to reveal an ever growing trend towards Euroscepticism. Almost sixty years after the signature of the Treaty of Rome in 1957 creating the European Economic Community (EEC), a Member-State, the United Kingdom (UK), has for the first time in history decided to leave the EU. Since then, the breeding grounds of anti-European movements have been growing exponentially, as the last elections to the European Parliament in June 2019 have shown: in almost every EU Member-State, Eurosceptic parties clearly increased their share of the votes, occupying more than a third of the seats in the new Parliament ${ }^{1}$. It was an ironic and almost absurd situation that those who were supposed to leave were legally obliged to participate in these elections, due to the failure to reach an agreement on Brexit in time. It was even more ironic that the majority of the new British Members of the European Parliament (MEPs) werz indeed "Brexiters", with the Brexit party gaining $30,5 \%$ of votes and 29 out of 73 seats $^{2}$. The rise of Anti-Europeanism was painfully illustrated during the opening session of the Parliament, when these MEPs turned their back in disregard of the European anthem being played ${ }^{3}$.

Available at: https://election-results.eu/national-results-overview/ [2-9-2019].

2 Available at: http://www.europarl.europa.eu/unitedkingdom/en/european-elections/ european_elections.html [2-9-2019].

3 "European Parliament opens amid protest and discord", $B B C$ News, 2-7-2019, available at: https://www.bbc.com/news/world-europe-48838498 [2-9-2019]. 
How under these circumstances not to agree with the mainstream view of Political Scientists that Euroscepticism seems to be a mainly British phenomenon and that it has originated in the UK? Whereas this article does not question British Euroscepticism as such, it does however challenge two orthodox view concerning the roots of anti-Europeanism. First, it contests that Euroscepticism has originated in 1980s, primarily being advocated by British political parties and by the Thatcher government. If defined as an opposition to the federalist European idea, Euroscepticism can indeed be traced back to the very beginning of the European integration process after the Second World War and can then be continuously followed up until today. Historians therefore prefer to use the umbrella term of "resistances to Europe" to designate Euroscepticism, as this term allows for a larger approach to the phenomenon deliberately moving away from its restrictive application to political parties. Second, it questions the so-called end of the permissive consensus in the 1990s. It argues, that, if public opposition against the EU has indeed amplified since then, this is primarily due to the frequent organization of referenda and the increasingly anti-European votes at European elections. However, it reveals a rather paradoxical link between European elections and Euroscepticism, as the latter are at the same time an expression of the democratic legitimacy of the European idea and of the rise of Euroscepticism.

\section{BEYOND BRITISH EUROSCEPTICISM IN THE 1980S: THE DEEP ROOTS OF ANTI-EUROPEANISM}

Political Scientists initially identified Euroscepticism as a British phenomenon entering the political arena in the 1980 s, notably with Margaret Thatcher's rejection of the EEC ${ }^{4}$. On the basis of an analysis of British party politics, they identified two types of opposition against Europe: the rejection of the principle underlying European integration itself (hard Euroscepticism) and opposition against its realization by the EEC and later by the EU (soft Euroscepticism)5. Their notion of Euroscepticism has been primarily developed with regard to party politics. Indeed, Szczebiak and Taggart elaborated a scale allowing for the classification of political parties depending on whether they are soft or hard Eurosceptics ${ }^{6}$. Kopecky and Mudde then developed a typology constructed on the basis of a distinction between an overall

\footnotetext{
Spiering (2004).

Szcerbiak y Taggart (2008).

$6 \quad$ Szcerbiak and Taggart (2003); Taggart (1998).
} 
opposition to the foundations of European integration (rejection of the principles of supra-nationality and market economy) and an opposition to the $\mathrm{EU}$ in its actual configuration ${ }^{7}$. Following on the grounds of these pioneer works, their research did not restrict itself to the British case only. Political Scientists realized indeed that it became necessary to integrate "historical" elements into the theoretical analysis, namely to confront them systematically with the respective chronological and national contexts. They have therefore progressively studied how opposition to Europe was constructed within certain national political spaces in the EEC/EU and increasingly focused their research on "cultural and historical variables" ${ }^{8}$ by analysing national discourses on European integration?. However, globally, all these studies closely linked Euroscepticism at its origins to the British opposition to Europe in the $1980 \mathrm{~s}^{10}$.

From a historical perspective, Euroscepticism can be traced back much further: Contemporary Historians claim indeed that opposition to Europe is as old as the idea of European integration itself ${ }^{11}$. Thus, after the Second World War, the hostility towards the European construction goes back to the first initiatives in favor of European unification. Starting with the creation of the Western Union and the Organization for European Economic Co-operation (OEEC) in $1948^{12}$, the European construction, embedded in the context of the Cold War, caused from the start intense opposition among Western Europe left wing parties and particularly the communists ${ }^{13}$. Some years later, the establishment of the European Coal and Steel Community (ECSC), the failure of the European Defense Community (EDC) and, along with it, of the European Political Community (EPC), remind us that ever since the beginning of European integration, neither European unity nor the forms that it may take were a matter of consensus ${ }^{14}$. Even the creation of the EEC was not achieved without opposition, as the vehement debates in the

\footnotetext{
7 Kopecky and Mudde (2002).

8 Harmsen and Spiering (2004); Neumayer and Zalewski (2008), and Dargent (2002).

9 Harmsen (2008); Diez Medrano (2003); Theiler (2004); Cautrès (2000), and Vignaux (2004).

10 Crespy and Verschueren (2010).

11 Lacroix and Coman (2007).

12 Bitsch (2004): 31.

13 Concerning the example of the French Communist Party, see Bossuat (1986).

14 See for example: Bossuat (1998): 33-45. For Roland Dumas, former French Minister of Foreign Affairs, the involvement in politics was motivated by the opposition against the EDC: Dumas (2009).
} 
Parliamentary Assembly of the Council of Europe prove ${ }^{15}$. As a result, and until the middle of the 1970s, the EEC has given the impression of a construction "without the peoples". With the establishment of the European Parliament, elected through universal suffrage in 1979, this lack of democracy should have been compensated. With little success, as has been shown by the turnouts of these elections ${ }^{16}$.

After the setting-up of the first European Organizations, Euroscepticism can then be traced back to the different crises of the process of European unification Margret Thatcher's contestation of the British budgetary contribution, know under the slogan "I want my money back" or her famous Bruges speech in 1988 constitutes just one of these crises which have accompanied the process of integration from the start ${ }^{17}$. As Historians have already illustrated, de Gaulle's policy of the empty chair in 1965 or the reluctant attitudes towards further integration steps during the period of "Euro-sclerosis" in the 1970s were for example two crises preceding the Thatcher era which revealed waves of Euroscepticism before the $1980 \mathrm{~s}^{18}$. Indeed, the reluctance of certain Member-States towards further steps of supranational European integration has been detected very early as an integral part of the history of the EEC, as Alan Milward put forward in his book on The European Rescue of the Nation State $^{19}$. Even when looking at the UK, opposition to a federal Europe can be traced back to the very beginning of the European integration process, when Winston Churchill held his Zurich speech on 19 September 1946, which was the starting point for the creation of the Council of Europe in 1949. Thus, whereas he affirmed the necessity to build up a United States of Europe, he also emphasized that the UK would not necessarily be part of this continental federation ${ }^{20}$. Winston Churchill was not the only Eurosceptic with regard to the federalist approach: The attitude of British unionists during the Congress of The Hague in May 1948 was clearly one of opposition to supranational integration and this attitude was largely supported by the Scandinavian participants of the Congress ${ }^{21}$. After the creation of the Council of Europe and the ECSC, when analysing certain political discourses in France, in the United Kingdom or in Germany, Eurosceptical attitudes can also already be

\footnotetext{
15 Wassenberg (2013b).

16 Libera et al. (2016).

17 Usherwood (2013).

18 Ludlow (2006); Bossuat and Loth (2001).

19 Milward (1992).

20 Ludlow (1997).

21 Guieu and Le Dréau (2009).
} 
observed in the $1950 \mathrm{~s}^{22}$. They can even be traced back to the inter-war period, especially when looking at the great many European projects of the 1920s and 1930s that failed due to a predominantly hostile opinion of the general public with regard to the idea of integration - a very typical characteristic of this period indeed ${ }^{23}$. It can therefore be asserted that Euroscepticism has been a part of process of European integration from the beginning of the discussions on the European idea.

When admitting that Euroscepticism has not necessarily originated from British party politics and that it is not merely an expression of opposition to the EEC/EU, it then follows that the terminology has to be reviewed from a historical perspective in a way to broaden the concept of what it means to "be against Europe".

\section{A WIDER DEFINITION THAN EUROSCEPTICISM: "RESISTANCES TO EUROPE"}

Not only Historians have realized that Euroscepticism seems too narrow as a term to englobe all sorts of anti-European attitudes. The research has therefore already given rise to a series of other terms that Political Scientists have used in order to constitute ever growing subcategories of Euroscepticism.

However, this terminological differentiation has not helped to define precisely what is meant by the origins of Euroscepticism. To the contrary, the terminology in Political Sciences has rather suffered from a "theoretical and terminological vagueness" ${ }^{24}$ which was sometimes cultivated on purpose. It allowed indeed for a conciliation of apparently very different and non-convergent elements of the "no" to Europe, thus making it possible to use a whole range of different terms to describe the same phenomenon: Euro-pessimism, Euro-phobia, Euro-rebellion, Euro-indifference ${ }^{25}$, Euro-phobia ${ }^{26}$, Euro-realism $^{27}$, critical Europeanism ${ }^{28}$ or Euro-cynicism ${ }^{29}$ are just some examples of

\footnotetext{
Müller-Härlin (2010).

Bitsch (2010).

Hamman (2010).

Delmotte (2007).

Rozenberg (2007).

Neumayer (2007).

Della Porta (2006).

Abst and Krouwel (2007).
} 
the inflationary sub-terminology used to designate different varieties of Euroscepticism. Beyond the proliferation of new words for the same phenomenon, this terminology also seems to suggest that there are objective ways how to classify different types and actors of Euroscepticism.

Historians however claim that we are not dealing with an objective analysis of the process of European integration, but rather with the manifestation of a series of negative emotions ${ }^{30}$ : fear of globalization, fear of the loss of one's job, of a social Europe, anger about the Brussels bureaucracy with innumerable European directives complicating the daily life and habits of the European people, but also disillusionment with a Europe that has not become a reality for the citizens, despite of all promises and political discourses. This is also why the first categorizations of hard and soft Euroscepticism appear somehow outdated today. From a historical perspective, this means that one has to acknowledge that a scientific theory on Euroscepticism can and does not exist and that we are rather dealing with a political and social phenomenon which is frequently expressed by certain components of the European population ${ }^{31}$. Amandine Crespy and Nicolas Verscheuren have therefore introduced in 2010 the expression "resistances to Europe" which allows them to cover a much larger panel of case studies and to go beyond the research focus on political parties only ${ }^{32}$. They insert the different subcategories of Euroscepticism into a more general approach which considers the historical concept developed by Pierre Renouvin and Jean-Baptiste Duroselle of the so-called "deep forces" (les forces profondes) in the history of international relations $^{33}$. Following this approach, the focus is placed on the motivations, the social background and the representations of actors opposing Europe. In fact, this larger definition has already been used by some Historians who attempted to trace back the phenomenon of opposition to the beginning of the European project (Jean-Michel Guieu, Jenny, Raflick, Christophe Le Dréau, and Laurent Warlouzet) ${ }^{34}$. They used it as a means in order to be able to study the process of opposition in the long run. This was not only necessary from their point of view ${ }^{35}$, but they were also encouraged to do so by many Political Scientists, for instance, Stefano Bartolini or Yves Déloye ${ }^{36}$. They recognized

\footnotetext{
30 Frank (2004); see also Girault (1994).

31 Loth and Barthel (2007).

32 Crespy and Verschueren (2010).

33 Renouvin and Duroselle (1964), and Frank (1988).

34 Guieu et al. (2006).

35 Lagrou (2006): 2209-2216.

36 Bartolini (2005) and Déloye (2000).
} 
that the state of opposition to Europe at a given moment was not sufficient to understand the dynamic process and evolution in time.

Following this historical approach, one also quickly realizes that there is no resistance to Europe in general. Rather, opposition to Europe manifests itself against certain representations of Europe ${ }^{37}$. Often, actors do not reject the idea of European integration itself, but their self-constructed representations of Europe or certain characteristics of the process of integration. These representations depend on the concept of European unification used, on the national origins of the actors concerned, but also on the chronological period or the fields of integration these actors focus on. Therefore, opposition to Europe is linked to a certain image of what is meant by Europe - or, in other words on the understanding of the "European identity" 38 . It is not necessarily a resistance to Europe on principle, but one that seeks to propose a different way to construct Europe -maybe an alternative Europe. For example, the initial opposition to European monetary integration in Germany in the 1980s was not really a rejection of the common currency itself, but rather of the underlying economic theory: the French monetarist approach and the fear of a lacking budgetary discipline ${ }^{39}$. In the same line of thought, the well-spread Euroscepticism in Scandinavian countries can be explained by their willingness to give priority to the so-called "Nordic cooperation" - which incidentally led to establishment of the European Free Trade Area (EFTA) in the 1960s. This cooperation was then proposed an alternative for the economic "formula" of the EEC, i.e. the Common Market. When applied to the concept of European identify, the Scandinavians rather identify themselves with a "Nordic Europe" as opposed to a "Western occidental Europe"40. Another example is the project of a "Europe of regions" that might be put forward as an alternative to the Europe of states as it has been implemented with the $\mathrm{EEC}^{41}$. In fact, certain actors, in this case the regional authorities in Europe, did not globally reject the idea of European integration, but they felt excluded form the project. Wishing to be associated with European integration, they sought an alternative political construct for the European project, where regional actors would occupy a key role. This form of "resistance" has even proven constructive for the process of integration, as shows the introduction, in 1992, of the principle of subsidiarity into the Maastricht Treaty, which

\footnotetext{
Réungoat (2010) y Marès (2014).

Pfister (2010) and Tréfàs (2010).

Fabbrini (2017).

Sitter (2001).

1 Bitsch (2010).
} 
allowed for a multi-level-governance approach characterized by an implication of national and regional actors into the European integration process ${ }^{42}$. Only a subversive anti-nation state regionalism leads to the rejection of the EU as a whole - thus to a destabilizing resistance to Europe.

When examining these different cases and periods of resistance to Europe, the question arises whether Euroscepticism as a whole has increased during time and if yes, whether this is due to the fact, as Political Scientists claim, that the British opposition to the EEC in the 1980s has led to the loss of a "permissive consensus" of the population on the very principle of European integration.

\section{QUESTIONING THE LOSS OF THE PERMISSIVE CONSENSUS IN THE $1990 \mathrm{~S}$}

Concerning the elaboration of a sort of time scale for resistance to Europe, it seems indeed evident that the phenomenon has strongly increased after the Treaty of Maastricht in 1992, when the process of European integration became a matter of public interest. The negative results in Denmark and slightly positive ones in France during the referenda following this Treaty sounded a first note of warning: the Eurosceptic voices seemed to suggest that Europe was made "from above" and did not take into consideration the interests and views of the European peoples ${ }^{43}$.

Political Scientists claim that this was the beginning of the loss of the so-called "permissive consensus" on the principle of European unification i.e., the end of the passive acceptance of this process by the European citizens $^{44}$. From then on, the growing demand for covering up the supposed democratic deficit apparently resulted in decreasing public support of the European integration process ${ }^{45}$. Researchers in Political Science indeed identified a growing aversion to the EU expressed by the European population and this could also lead to blockages in the EU institutions themselves ${ }^{46}$. As a proof, they quote the majority "no" votes in various referenda organised by some EU Member-States on the occasion of the European

42 Wassenberg (2012): 98.

43 See interview with Hubert Védrine by Frédéric Clavert, Paris, 2008, availible at: https://bit.ly/3kHydSI [9-9-2019].

44 Lindberg and Scheingold (1970).

45 Manigand and Dulphy (2004).

46 Brack and Costa (2014). 
Treaty reforms of Maastricht and Nice, on the European Constitution, on the Lisbon Treaty and, more recently, the "yes" vote for Brexit by the British population ${ }^{47}$. Possible explanations for this increase in Euroscepticism in the 1990s ranged from an alleged lack of democratic legitimacy of European institutions, an ever growing distance between the Brussels bureaucracy and the European citizens to the accusation of the EU being elitist and the failure of its political leaders to make the European organization comprehensible and approachable for the population ${ }^{48}$. But other reasons have been put forward since the 2000s, especially the hypothesis that the increase in "no" votes to Europe is due to the EU having been afflicted by severe internal and external crises. The rejection of the draft of the EU constitution by the negative referenda of the Dutch and French population in 2005 was the beginning of this trend, as it abruptly stopped the euphoria that had accompanied the process of European integration ${ }^{49}$. The rescue bid of the so-called "simplified" Lisbon Treat ${ }^{50}$ had barely relaunched the European zest in 2008 when the international economic and financial crisis destabilized the Euro-zone within the EU to such an extent that Greece was threatened with exclusion from the monetary union - a reason to explain the growing discontent of the Greek population. And while the EU MemberStates were still haggling with each other over reform packages to solve this crisis, the next one was already beginning to emerge: For years, the refugee problem had been visible at the maritime borders of Italy, Spain and Greece as well as at the Schengen border of the Channel Tunnel between Calais and Dover - a problem worrying the population of the Member-States directly concerned ${ }^{51}$. In summer 2015, it escalated when Hungary blocked its external border, and the Dublin agreement was suspended. In addition, since the failed attempt at an economic agreement with Ukraine and the resulting conflict between Russia and Ukraine in 2014, the EU has been fighting for the reputation of its tediously established European Neighborhood Policy. Finally, in 2015, the Brexit seems to indicate the peak of anti-Europeanism and its disastrous consequences for the EU. According to Political Scientists, one the negative consequences of these crises is that the "permissive consensus" no longer exists and that Euroscepticism has become

\footnotetext{
Libera (2016): 10-25.

Rambour (2010).

49 The European Constitution was rejected by the French with 54, 7\% and by the Danes with 61, 6\%.

50 The Irish initially rejected the Lisbon Treaty actually with $67 \%$ of the votes.

51 Wassenberg (2017).
} 
a generalized phenomenon concerning large parts of the population in Europe $^{52}$.

From a historical perspective, this argumentation can be questioned. From the beginning, the process of Europe integration has not profited from a smooth public support or a European consensus. As soon as in August 1949, when the first meeting of the Consultative Assembly of the Council of Europe took place in Strasbourg, there were violent manifestations by French communists and anti-German movements against the first European Organization to the point that Robert Schuman introduced a Court case against them at the Prefecture ${ }^{53}$. After the Schuman Declaration in May 1950, the ECSC was violently denounced as an ultra-liberal capitalist project by most European Trade Unions and Workers Organizations ${ }^{54}$. Also, the Maastricht referendum was not the first revelation of lacking support of the population to the European Integration process. Thus, the Norwegians rejected the accession to the EEC by referendum in 1972 (and they voted a second time against the EU in 1994) and the UK population had already shown a considerable mistrust against the EEC when the first referendum on membership was organized in 1975 , for $33 \%$ of the British citizens already expressed then their opposition to Europe at that time ${ }^{55}$.

In general, it can be maintained that the "permissive consensus" was assumed to exist, because there were not many referenda organized from 1957 until 1992. This was due to the fact that the European Treaties were not modified until the Single European Act in 1986 and that, consequently, the EEC Members-States did not need to organize referenda on their adoption. Only from 1987 onwards, with the successive European Treaty reforms there was a constitutional obligation for some EU Member-States to consult their population ${ }^{56}$. It is therefore quite possible that, had there been other referenda organized before 1992, there might have been other majority "no" votes expressed by the European population.

But Political Scientists also insist that the loss of the permissive consensus can be proven by the growing success of anti-European political parties during European elections, especially since the EU Eastern enlargement in 2005/2007 and the subsequent economic crisis in 2008. It is indeed undeniable that in the

\footnotetext{
Hooghe and Marks (2008).

Bitsch (1997) and Wassenberg (2013a): 20-30.

Warlouzet (2014).

Rye (2018).

Maastricht (1992), Amsterdam (1997), Nice (2001), the European Constitution (2004) and the Lisbon Treaty (2007), see Beach (2018).
} 
late 2000s, Eurosceptical forces have increased their share of seats in the European Parliament. The results of the European elections in 2009, in 2014 and in 2019 clearly show an increase of what are generally called "Eurosceptic" political forces and this in nearly all EU Member-States ${ }^{57}$. The three anti-European fractions in the European Parliament, i.e. the European Conservatives and Reformists (ECR) $)^{58}$, the Europe of Free and Direct Democracy (EFDD) ${ }^{59}$ and the European United Left - Nordic Green Left (GUE-NGL) ${ }^{60}$ held 124 seats during the 2009-2014 electoral period, i.e. $17.6 \%$ of the votes ${ }^{61}$ and increased their share to 171 seats, i.e. $22.8 \%$ in the 2014 elections. The outcome for Eurosceptics in 2014 was even significantly higher, because not all anti-European political parties were members of a faction: In 2015, when Marine Le Pen and Marcel de Graaff launched the Europe of Nations and Freedom (ENF) group, mainly composed of the French Front National, Geert Wilders' Dutch Party of Freedom, they introduced in fact a third right-wing anti-European faction counting $39 \mathrm{MEPs}^{62}$. In the 2019 European elections, the rising trend of Euroscepticism was clearly confirmed. Even if the ECR and the GUE-NGL respectively lost 8 and 9 seats with regard to 2014, the overall score of Eurosceptic parties was higher, mainly because at the far-right, the ENF made the second biggest gains of the elections, propelled by the success of Italy's League (Lega) and France's National Rally (Rassemblement National). The now newly labelled group "Identity and Democracy" (ID) received 74 votes and together with the ECR and the GUE-NGL they hold 176 seats in the European Parliament ${ }^{63}$. This success somehow however conceals the fact that the EFDD group has disappeared and that its anti-European parties have been integrated into the other Eurosceptic factions, mainly the ID. But is this high Eurosceptic political party representation in the European Parliament due to the loss of the permissive consensus on European integration?

Moreau and Wassenberg (2016a, 2016b).

58 The ECR regroups Eurosceptic conservative parties (for example the Czech Civic Democratic Party, the German Alternative für Deutschland, the British Conservative Party and the Finns Party).

59 The EFDD regroups national populist and far right parties (Danish People's Party, Italian Five Star Movement, Sweden Democrats).

60 The GUE-NGL regroups far left-wing political parties (for example the Cypriote Progressive Party of Working People, the German Linke, the Irish Sinn Fein, or the Spanish Podemos).

61 Veivodová (2016).

62 Wassenberg (2019): 282.

63 Available at: https://europeelects.eu/ep2019 [2-9-2019]. 
From a historical perspective, the rise in the share of seats won by Eurosceptic parties does not necessarily mean that opposition to Europe has not before been represented in the European Parliament. Indeed, when looking at the history of the European elections, Eurosceptic forces have entered the European Parliament from the very start: after the 1979 elections, the fraction of the European Conservatives (ED) composed of the Eurosceptic British Conservatives held 64 seats and among the $44 \mathrm{MEPs}$ of the group of Communists and the Far Left, there were a strong proportion of "hard" Eurosceptics $^{64}$. Then, in 1985, the EEC hostile Front National (FN) made its entry into the European Parliament with 16 seats and during the following election, in 1989, the Eurosceptic ultra-regionalists (RBW) followed, gaining 13 seats $^{65}$. Thus, Eurosceptic political parties have constituted a founding element of a democratically pluralistic European Parliament, in which all conceptions and ideas on Europe could be represented, i.e. also those opposing the EEC/EU.

Besides, when identifying anti-European movements in the European Parliament, we have to take into consideration, that within the political spectrum, the "classic" marginal parties from the left or right wing extreme camp (neo-communist, post-communist, national-populist, and right-wing extremist groups) might not be the exclusive advocators of Euroscepticism. It is true, that since the 2000s, new anti-European parties have entered the scene (for example the Five-Star-Movement in Italy Podemus in Spain or the Alternative für Deutschland (AfD) in Germany), but the so-called mainstream parties (like the German Social Democrats, the British Labour Party or the French neo-Gaullists) also increasingly champion Eurosceptic positions ${ }^{66}$. Indeed, if one admits that "argumentative models of opposition to Europe" 67 might be potentially found in every political party, then mainstream political parties might be just as anti-European as political parties from the extreme right or left wing spectrum and this is not necessarily visible at first sight, when looking at the seat distribution, factions and group affiliations within the European Parliament ${ }^{68}$. Also, political parties can shift their position on Europe in time, as for example the Spanish communist party, which was originally pro-European and has become increasingly Eurosceptic ${ }^{69}$. It can therefore be argued that any political party might potentially partake in the process

\footnotetext{
64 Libera et al (2016): 20.

65 Wassenberg and Schirmann (2019).

66 Moreau and Wassenberg (2016a): 20-40.

67 Müller-Härlin (2010):142-143.

68 Forster (2002).

69 Forner and Senante (2019).
} 
of resistance to Europe and that the anti-European labelled political forces in the European Parliament can be interpreted as "the top of the iceberg" under which many other Eurosceptic tendencies might be hidden ${ }^{70}$.

One may however wonder why anti-Europeanism does assert itself with such magnitude at the time of the European elections. The history of the European elections reveals indeed a very complex, almost paradoxical situation concerning their link with Euroscepticism.

\section{A PARADOXICAL LINK BETWEEN EUROPEAN ELECTIONS AND EUROSCEPTICISM}

There are at least three paradoxes which can be revealed when analyzing resistances to Europe through a historical perspective on the turnout of European elections and which underline the argument that public opinion "cannot simply be characterized as either Eurosceptic or not, but rather consists of different types"71. These types depend on the way how Euroscepticism was expressed at European elections and by the historical context when it was expressed.

The first paradox concerns the fact that the direct European elections were introduced as an element of democratization of the EEC and to increase public support for the European integration process, but this was apparently not the case, as the first direct elections in 1979 showed. In principle, in the collective imagination, the direct election of the European Parliament -a democratic act by definition - was supposed to bring Europe closer to its citizens and strengthen their feeling of belonging to the EEC. In the 1950s, the fathers of Europe therefore saw in this election by universal suffrage the means of consolidating European integration. Robert Schuman was indeed convinced that citizens were more in support of Europe than the politicians and he repeatedly said that citizens must be relied on to advance European integration. As early as 1956, he proposed a European Parliament elected by direct suffrage and this was then taken up by a provision in the Treaty of Rome $^{72}$. But in 1960, when the European Parliamentary Assembly drew up a concrete proposal on organizing the European elections by direct universal suffrage, this was rejected at the time by the French authorities - an ostensive sign of de Gaulle's opposition to a federal Europe ${ }^{73}$.

\footnotetext{
Wassenberg (2019): 291.

De Vries (2018).

Deloye (2005): 35.

3 Wassenberg (2007).
} 
When the decision was finally taken in the mid-1970s and preparations were made for the European elections in June 1979, everyone expected it to be a qualitative leap for European integration and a means to address the democratic deficit in the EEC ${ }^{74}$. However, at that time, Euroscepticism was the overall mood in the EEC Member-States and surprisingly, during the European elections, the citizens did not mobilize massively, either in support of European integration, or even to vote. From that first experience, the abstention rate, which was quite low in countries where voting is compulsory (Belgium, Italy, Luxembourg), reached on average 37\% in the Community of nine Member-States ${ }^{75}$. Many circumstances can explain these reserves. Europe was coming out of the three post-war decades' boom: unemployment, high oil prices and the economic crisis were (again) affecting Europe. The EEC, which had expanded since 1973, was struggling to integrate the UK which had elected to power the first resolutely Eurosceptic head of government in the Community - Margaret Thatcher. In the next elections in 1984, the lack of enthusiasm remained and for some years, voice was given to this mistrust also in the media: it was regularly evaluated by the polls, including the Eurobarometer ones, which normally rather seek to measure the degree of adherence $^{76}$. Facts must be faced: there were structural and conjunctional reasons for the poor turnout at elections and for Euroscepticism.

This brings to the surface another element to consider when analyzing the link between European elections and Euroscepticism: the role and interpretation of the degree of abstention. At first glance, abstention seems to come under indifference rather than hostility. But it probably means a less benevolent indifference than that which Political Scientists understand as "the permissive consensus" 77 . It could indeed be interpreted as disinterest in, mistrust of or even as rejection of the EEC/EU. The rate of abstention in the European elections has increased constantly between 1979 and $2014^{78}$. But the interpretation of the meaning of abstentions stays ambiguous. First, there were always considerable variations according to the EU Member-States concerned. To illustrate this by an example, during the European elections in 2014, the abstention rate was situated between 10 and $87 \%$ : in Luxemburg and Belgium where the vote is obligatory it was $10-15 \%$, whereas in Slovakia

\footnotetext{
74 Bernard (2016).

75 Bertoncini and Chopin (2014).

76 Rambour (2010): 95.

77 However, and the rising degree of abstention weakens the legitimacy of the European Parliament, Costa (2001).

78 Rambour (2016).
} 
it reached the highest rate in the EU of $87 \%$. Second, with an average of 42, $5 \%$, abstention at European elections was at about the same level as in some national elections of EU Member-States. It was therefore not abnormally high and a blank or invalid ballot paper might thus be representative more of a rebellious attitude towards the principle of elections and the political establishment than of opposition to Europe. And, finally, the rate of abstention has decreased in the 2019 European elections, at a time when "hard" Eurosceptic political parties were more than ever advocating violently their opposition to the EU: the overall European average participation was $51 \%$ at these last elections. Indeed, in 3 out of 4 EU Member-States, participation was situated at a level above $50 \%$ and it was especially high in Central and Eastern European Member-States (Poland, Hungary, Slovakia, the Czech Republic and Rumania) where Eurosceptic attitudes had been increasing with regard to new Community measures, for example in the field of migration ${ }^{79}$. This seems to support the argument that abstention does reveal indifference rather than opposition, because when the EU matters or even divides public opinion, people go and vote, for or against European integration.

A third paradox is the fact, that the population might not even necessarily express opposition to Europe when voting for anti-European political parties. This paradox is a consequence of the very nature of the European elections and the way how they are organized. Michel Hastings, who studied the 2004 elections, wrote: "This is not a European poll”, meaning that in fact, it was rather a juxtaposition of a series of national elections ${ }^{80}$. Several factors contributed to this "national appropriation" of the European elections: first, they are not held on exactly the same date in all Member-States but are spread out over four consecutive days, from Thursday to Sunday, taking into account the different voting habits in the various countries; second, the voting rules are still not uniform even if they are gradually becoming more similar; third, electoral lists are comprised of national candidates; and, finally election campaigns have so far always been strongly influenced by national concerns and the political issues discussed were often more national-oriented than European. However, the national importance of these elections has also been quite weak in the past, as they neither determine the parliamentary majority nor the composition of the national government ${ }^{81}$. Thus, they were often considered to be "low priority", "intermediary" or "subsidiary" elections, like local elections. This weakness of the issues at stake may explain the voter's

\footnotetext{
79 Available at: https://bit.ly/3heps08 [2-9-2019].

80 Hastings (2005).

81 Hrbek (2019).
} 
apathy or their opposition, not to Europe but to their own national state: citizens may be tempted to abstain or to cast a protest vote against their national government ${ }^{82}$.

Moreover, European elections are still considered unimportant by large parts of the population because the European Parliament is still perceived by them as the weak link in the institutional system, which it has indeed been for a long time. Since Maastricht, treaty by treaty, however, the Parliament has gained a lot of power, even if it is still not comparable to a national Parliament, for it is not the sole legislator of the $\mathrm{EU}^{83}$. New powers have been added, little by little, to the original supervisory powers and the right to censure, for example budgetary power (to adopt or reject the annual budget). It therefore does now have major legislative power thanks to the co-decision procedure with the Council (of Ministers) for numerous texts, as well as the possibility to influence the composition of the Commission by the nomination of its members, but the population is not necessarily aware of this shift of power. To stress the importance of European elections, during the 2014 campaign, the main political families in Europe had even each chosen a leader who was claiming the Commission presidency if his side was to win the election, but this procedure has been dropped again in 2019, although the Spitzenkandidat of the European People Party (EPP), Manfred Weber, had tried to maintain it. If the European population had believed that they could choose a European leader in the 2019 elections, they found themselves deceived, for the Commission President, Ursula von der Leyen, had not been a candidate and was finally designated by the European Council — without consultation of the European people. The paradoxical link between European elections and Euroscepticism therefore still exists and finds itself even fortified when looking at the aftermath of the 2019 European Parliament elections.

\section{CONCLUSION}

Joy, bright spark of divinity, Daughter of Elysium, fire-inspired we tread thy sanctuary, thy magic power re-unites all that custom has divided, all men become brothers under the sway of thy gentle wings ${ }^{84}$.

Bitsch (2016).

83 Greenwood and Roederer-Rynning (2019).

84 First strophe of the European hymn from the "Ode to Joy" of Beethoven's Ninth symphony, different versions of this hymn can be heard on the Council of Europe 
When in 1972 the Council of Europe chose as European hymn, the excerpt from the "Ode to Joy" of Beethoven's Ninth symphony, European idealism seemed to be at its top. The European unification practically became the sanctified, blessed undertaking, Europe a place of joy, surrounded by divine sparkles, an angelic place, in which through the spell of Gods men live in peace and unity.

The reality of today's Europe is far away from this vision. Pessimism, Euroscepticism and opposition have for long made a stand against the idealized transfiguration of the European unification process. In the current context of "Brexit", when anti-European declarations in the UK make the headlines of the media in Europe every day, one is tempted to see in this evolution the confirmation of what Political Scientists claimed in their first analysis of Euroscepticism: that we are dealing with a phenomenon that has originated in British party politics in the 1980s and has then spread to the rest of Europe, mainly with the progressive loss of the so-called "permissive consensus" by the European population.

When analyzing the history of European integration, this assumption needs to be qualified, if not put into question. Opposition to Europe can indeed be traced back to the very beginning of the European integration process in the 1950s, if not to the beginning of the debates on the European idea in the 1920s. If defined as "resistances to Europe", Euroscepticism then turns out to be a very complex phenomenon: it is neither limited to party politics, nor homogenous in its manifestations nor constantly represented or equally strong in all European countries, nor static or unmovable, but on the contrary a dynamic process changing from time to time, which develops further along the history of European integration. Therefore, this phenomenon is nothing new: it is like a "headwind" which accompanies and hinders the protagonists of the European unification process, similar to a cyclist ${ }^{85}$. And the categorizations initially proposed by the Political Scientists, such as "hard" or "soft" Euroscepticism have long been outmoded and should be replaced by a forces profondes - approach known in historical sciences, which includes the motivations, backgrounds and representations of all relevant actors in an analysis of European or global history. One could regard this as a first answer by historian's to the research on Euroscepticism which has so far been rather dominated by the field of Political Sciences.

Assuming that there has been a "permissive consensus" on European integration is underestimating the forces profondes that operate below the

\footnotetext{
website under "Symbols ", www.coe.int [2-9-2019].

85 Blanc (2010).
} 
surface of what appears as the iceberg of the history of European integration. Therefore, if European referenda and the turnout of European elections since the Maastricht Treaty in 1992 do reveal a growing success of "no" voices and Eurosceptic political parties, this does not necessarily stem from a "loss of a permissive consensus" of the European population. Opposition against Europe has indeed already been expressed in referenda before 1992 and it has accompanied the European elections from their very start in 1979. Thus, Eurosceptic parties have always been represented in the European Parliament, reflecting the pluralistic value of democracy, even if it is true that the rejection forms or the enmity towards Europe, from being limited to political fringe groups, have now developed to a "normalized" attitude of the European population towards the European unification process and the European institutions. The paradox of European elections is that they have often been misused as an occasion to express general political disinterest or discontent with national politics rather that to vote for or against Europe.

\section{Bibliography}

Abst, K. and Krouwel A. (2007). Varieties of Euroscepticism and populist mobilization: transforming attitudes from mild Euroscepticism to harsh Eurocynicism. Acta Politica, 42 (2-3), 252-270. Available at: https://doi.org/10.1057/palgrave.ap.5500187.

Bartolini, S. (2005). Restructuring Europe. Oxford: Oxford University Press. Available at: https://doi.org/10.1093/0199286434.001.0001.

Beach, D. (2018). Referendums in the European Union. Oxford Research Encyclopedias, Political Values, Beliefs, and Ideologies, World Politics. Available at: https://doi. org/10.1093/acrefore/9780190228637.013.503.

Bernard, E. (2016). L'élection européenne de 2014: Vers une Union plus démocratique? In M. Libera, S. Schirmann and B. Wassenberg (eds.). Abstentionnisme, euroscepticisme et anti-européisme dans les élections européennes de 1979 à nos jours (pp. 31-45). Stuttgart: Steiner-Verlag.

Bertoncini, Y. and Chopin, T. (2014). Des visages sur des clivages. Les élections européennes de mai 2014. Notre Europe, Etudes et rapports.

Bitsch, M. T. (1997), Jalons pour une histoire du Conseil de l'Europe. Berne: Peter Lang.

- (2004). Histoire de la construction européenne, de 1945 à nos jours. Bruxelles: Complexe.

- (2010). Préface. In B. Wassenberg, F. Clavert and P. Hamman (eds.). Contre l'Europe? Anti-européisme, euroscepticisme et alter-européisme dans la construction européenne de 1945 à nos jours (vol. 1): les concepts (pp. 19-27). Stuttgart: Steiner Verlag.

- (2016). Introduction. In M. Libera, S. Schirmann and B. Wassenberg (eds.). Abstentionnisme, euroscepticisme et anti-européisme dans les élections européennes de 1979 à nos jours (pp. 15-31). Stuttgart: Steiner Verlag. 
Blanc, M. (2010). Postface: rêves d'Europe. In B. Wassenberg, F. Clavert and P. Hamman (eds.). Contre l'Europe ?, Anti-européisme, euroscepticisme et alter-européisme dans la construction européenne de 1945 à nos jours (vol. 1): les concepts (pp. 449-489). Stuttgart: Steiner Verlag.

Bossuat, G. (1986). L'aide américaine à la France après la Seconde Guerre mondiale. Vingtième siècle, 9 (9), 17-36. Available at: https://doi.org/10.3406/xxs.1986.1445.

- (1998). La campagne de Daniel Mayer contre la CED, Matériaux pour l'histoire de notre temps, 51 (51-52), 33-45. Available at: https://doi.org/10.3406/mat.1998.404206.

— and Loth, W. (eds.) (2001). Crises and compromises, the European project, 1963-1969. Bruxelles: Bruylant.

Brack, N. and Costa, O. (eds.) (2014). Euroscepticsm within the EU institutions. Diverging Views of Europe. Abingdon: Routeledge.

Cautrès, B. (2000). Les attitudes des Français à l'égard de l'Union européenne: les logiques du refus. In P. Brechon, A. Laurent and P. Perrineau (eds.). Les cultures politiques des Français (pp. 323-354). Paris: Presses de Science Po.

Costa, O. (2001). Le Parlement européen, assemblée délibérante. Bruxelles: Éditions de l'Université de Bruxelles.

Crespy, A. and N. Verschueren (2010). Les résistances à l'Europe: une approche interdisciplinaire des conflits sur l'intégration européenne. In B. Wassenberg, F. Clavert and P. Hamman (eds.). Contre l'Europe?, Anti-européisme, euroscepticisme et alter-européisme dans la construction européenne de 1945 à nos jours (vol. 1): les concepts (pp. 121-141). Stuttgart: Steiner Verlag.

Dargent, C. (2002). Citoyenneté européenne: la concurrence des identités territoriales et sociales. In B. Cautrès and D. Reynie (eds.). L’opinion européenne 2000 (pp. 47-69). Paris: Presses de Sciences-Po.

De Vries, C. E. (2018). Euroscepticism and the Future of European Integration. Oxford: Oxford University Press. Available at: https://doi.org/10.1093/oso/9780198793380.001.0001.

Della Porta, D. A. (2006). The anti-globalisation and the European Union: critics of Europe. Notre Europe, Policy Paper, 22.

Delmotte, F. (2007). Les résistances à l'Europe au prisme de la sociologie historique de Norbert Elias. In J. Lacroix and R. Coman (eds.). Les résistances à l'Europe. Cultures nationales, idéologies et stratégies d'acteurs (pp. 17-29). Bruxelles: Éditions de l'université de Bruxelles.

Déloye, Y. (2000). Exploring the Concept of European Citizenship. A Socio-Historical Approach. Yearbook of European Studies, 14, 197-219. Available at: https://doi. org/10.1163/9789004333369_011.

— (ed.). (2005). Dictionnaire des élections européennes. Paris: Economica.

Díez Medrano, J. (2003). Framing Europe: attitudes to European integration in Germany, Spain and the United Kingdom. Princeton: Princeton University Press.

Dumas, R. (2009). Affaires étrangères, tome 1: 1981-1988. Paris : Fayard.

Fabbrini, S. (2017). Which European Union? Europe after the Euro Crisis. Cambridge: Cambridge University Press. 
Forner, S. and Senante, H. C. (2019). The European policy of the Spanish Communist Party (1972-1999): From the pro-European switch to Euroscepticism. Historica y Politica, 41, 335-366.

Forster, A. (2002). Euroscepticism in Contemporary British Politics: Opposition to Europe in the Conservative and Labour Parties Since 1945. Abingdon: Routledge. Available at: https:// doi.org/10.4324/9780203402665.

Frank, R. (1988). Histoire des relations internationales contemporaines. Paris: Masson.

(2004). Les identités européennes au XXe siècle. Diversités, convergences et solidarités. Paris: Publications de la Sorbonne. Available at: https://doi.org/10.4000/books. psorbonne.739.

Girault, R. (1994). Identité et conscience européennes au XXe siècle. Paris: Hachette.

Greenwood, J. and Roederer-Rynning, C (2019). Taming Trilogues: The EU-s Law-making Process in a Comparative Perspective. In O. Costa (ed.). The European Parliament in times of EU crisis. Dynamics and Transformations (pp. 121-143). Cham: Palgrave. Available at: https://doi.org/10.1007/978-3-319-97391-3_6.

Guieu, J. M., Raflick, J., Le Dréau, C. and Warlouzet, L. (ed.). (2006). Penser et construire l'Europe au XXe siècle. Paris: Belin.

Guieu, J. M. and Le Dréau, C. (eds.) (2009). Le Congrès de l'Europe à la Haye (1948-2008). Bruxelles: Peter Lang.

Hamman, P. (2010). Un regard sociologique : penser les résistances à la construction européenne, des concepts aux territoires. In B. Wassenberg, F. Clavert and P. Hamman (eds.). Contre l'Europe? Anti-européisme, euroscepticisme et alter-européisme dans la construction européenne de 1945 à nos jours (vol. 1): les concepts (pp. 39-61). Stuttgart: Steiner Verlag.

Harmsen, R. (2008). The evolution of Dutch European discourse: defining the limits of Europe. Perspectives on European Politics and Society, 9 (3), 316-341. Available at: https://doi.org/10.1080/15705850802223440.

and Spiering, C. (2004). Introduction: Euroscepticism and the evolution of the European political debate. In R. Harmsen and C. Spiering (eds.). Euroscepticism: party politics, national identity and European integration (pp. 13-35). Amsterdam: Rodopi. Available at: https://doi.org/10.1163/9789401201087_002.

Hastings, M. (2005). Les élections européennes de juin 2004. In Y. Deloye (ed.). Dictionnaire des élections européennes (pp. 536-541). Paris: Economica.

Hooghe, L. and Marks, G. (2008). A Postfunctionalist Theory of European Integration: From Permissive Consensus to Constraining Dissensus. British Journal of Political Science, 39 (1), 1-23. Available at: https://doi.org/10.1017/S0007123408000409.

Hrbek, R. (2019). The Arduous Way Towards a Uniform Electoral System for the European Parliament. In O. Costa (ed.). The European Parliament in times of EU crisis. Dynamics and Transformations (pp. 255-275). Cham: Palgrave. Available at: https://doi. org/10.1007/978-3-319-97391-3_12.

Kopecky, P. and Mudde, C. (2002). The two sides of Euroscepticism: party positions on European integration in East Central Europe. European Union Politics, 3 (3), 297-326. Available at: https://doi.org/10.1177/1465116502003003002. 
Lacroix, J. and Coman, R. (eds.) (2007). Les résistances à l'Europe. Cultures nationales, idéologies et stratégies d'acteurs. Bruxelles: Éditions de l'université de Bruxelles.

Lagrou, P. (2006). "Resistance", Europe Since 1914. Encyclopedia of the Age War and Reconstruction. New York: Thomson/Gale.

Libera, M. (ed.) (2016). L'Europe contestée. Paris: L'Harmattan.

- , Schirmann, S. and Wassenberg, B. (eds.) (2016). Abstentionnisme, euroscepticisme et anti-européisme dans les élections européennes de 1979 à nos jours, Stuttgart: Steiner-Verlag.

Lindberg, L. and Scheingold, S. (1970). Europe's would-be polity: patterns of change in the European Community. Englewood Cliffs: Prentice Hall.

Loth, W. and Barthel C. (2007). Cultures politiques, opinions publiques et intégration européenne. Bruxelles: Bruylant.

Ludlow, P. N. (1997). Dealing with Britain, the Six and the first UK application to the EEC. Cambridge: Cambridge University Press.

- (2006). The European Community and the crises of the 1960s: negotiating the Gaullist challenge. London: Routledge.

Manigand, C. and Dulphy, A. (2004). Les opinions publiques face à l'Europe communautaire. Bruxelles: Peter Lang.

Marès, A. and Rey, M. P. (2014). Mémoires et émotions : Au cour de l'histoire des relations internationales. Paris: Publications de la Sorbonne.

Milward, A. (1992). The European rescue of the Nation State. London: Routledge.

Moreau, P. and Wassenberg, B. (eds.) (2016a). European Integration and new Anti-Europeanism I. The 2014 European Election and the Rise of Euroscepticism in Western Europe. Stuttgart: Steiner Verlag.

(2016b). European Integration and new Anti-Europeanism II. The 2014 European Election and New Anti-European Forces in southern, Northern and Eastern Europe. Stuttgart: Steiner Verlag.

Müller-Härlin, M. (2010). Die Gegner Europas: Argumentationsmuster im politischen Diskurs. In B. Wassenberg, F. Clavert and P. Hamman (eds.) (2010). Contre l'Europe? Anti-européisme, euroscepticisme et alter-européisme dans la construction européenne de 1945 à nos jours (vol. 1): les concepts (pp. 141-155). Stuttgart: Steiner Verlag.

Neumayer, L. (2007). Euroscepticism as a political label: The use of European Union issues in political competition in the New Member States. European Journal of Political Research, 47, 135-160. Available at: https://doi.org/10.1111/j.1475-6765.2007.00721.x.

Neumayer, R. A. and Zalewski, F. (eds.) (2008). L'Europe contestée. Espaces et enjeux des positionnements contre l'intégration européenne. Paris: Lignes de Repères.

Pfister, E. (2010). Die Identität Europas und Europabilder in Wochenschauen nach 1945. In B. Wassenberg, F. Clavert and P. Hamman (eds.). Contre l'Europe? Anti-européisme, euroscepticisme et alter-européisme dans la construction européenne de 1945 à nos jours (vol. 1): les concepts (pp. 233-249). Stuttgart: Steiner Verlag.

Rambour, M. (2010). Les oppositions à l'Europe sont-elles structurées politiquement? In B. Wassenberg, F. Clavert and P. Hamman (eds.). Contre l'Europe?, Anti-européisme, euroscepticisme et alter-européisme dans la construction européenne de 1945 à nos jours (vol. 1): les concepts (pp. 93-109). Stuttgart: Steiner Verlag. 
(2016). Des élections européennes sans électeurs? De quelques caractéristiques électorales (1979-2009)? In M. Libera, S. Schirmann and B. Wassenberg (eds.). Abstentionnisme, euroscepticisme et anti-européisme dans les élections européennes de 1979 à nos jours (p. 65). Stuttgart: Steiner-Verlag.

Renouvin, P. and Duroselle, J. B. (1964). Introduction à l'histoire des relations internationales. Paris: Armand Colin.

Réungoat, E. (2010). Les résistances partisanes à l'Europe dans les partis français : enjeux de présentation de soi et de labellisation. In B. Wassenberg, F. Clavert and P. Hamman (eds.). Contre l'Europe? Anti-européisme, euroscepticisme et alter-européisme dans la construction européenne de 1945 à nos jours (vol. 1): les concepts (pp. 155-175). Stuttgart: Steiner Verlag.

Rozenberg, O. (2007). La faute à Rousseau? Les conditions d'activation des quatre idéologies critiques de la construction européenne en France. In J. Lacroix and R. Coman (eds.). Les résistances à l'Europe. Cultures nationales, idéologies et stratégies d'acteurs (pp. 129-154). Bruxelles: Éditions de l'université de Bruxelles.

Rye, L. (2018). Norvegian Euroscepticism Revisited: The Gap between Policy and Practice. In P. Moreau and B. Wassenberg (eds.). European Integration and new Anti-Europeanism III, Perceptions of external States on European Integration (pp. 31-45). Stuttgart: Steiner Verlag.

Sitter, N, (2001). The politics of opposition and European integration in Scandinavia: is Euroscepticism a government-opposition dynamic?. West European Politics, 24 (4), 22-39. Available at: https://doi.org/10.1080/01402380108425463.

Spiering, M. (2004). British Euroscepticism. In R. Harmsen and M. Spiering (eds.). Euroscepticism: party politics, national identity and European integration (pp. 127-150). Amsterdam: Rodopi. Available at: https://doi.org/10.1163/9789401201087_007.

Szcerbiak, A. and Taggart, P. (eds.) (2003). Theorising party-based Euroscepticism: problems of definition, measurement and causality. Sussex: Sussex European Institute.

- (2008). Opposing Europe? The comparative party politics of Euroscepticism. Comparative and theoretical perspective. Oxford: Oxford University Press.

Taggart, P. (1998). A touchstone of dissent: Euroscepticism in contemporary Western European party systems. European Journal of Political Research, 33 (3), 363-388. Available at: https://doi.org/10.1111/1475-6765.00387.

Theiler, T. (2004). The origins of Euroscepticism in German-speaking Switzerland. European Journal of Political Research, 43 (4), 635-656. Available at: https://doi.org/10.1111/ j.1475-6765.2004.00168.x.

Tréfàs, D. (2010). Die Vielfalt der Euroskeptizismen in der öffentlichen Kommunikation: eine Analyse der Debatte um die europäische Verfassung 2005 in der deutschen und der britischen Kommunikationsarena. In B. Wassenberg, F. Clavert and P. Hamman (eds.). Contre l'Europe? Anti-européisme, euroscepticisme et alter-européisme dans la construction européenne de 1945 à nos jours (vol. 1): les concepts (pp. 249-269). Stuttgart: Steiner Verlag.

Usherwood, S. (2013). Margaret Thatcher and British Opposition to European Integration: Saint or Sinner? In M. Gainar and M. Libera (eds.). Contre l'Europe? Ani-européisme, euroscepticisme et alter-européisme dans la construction européenne de 1945 à nos jours 
(Volume 2): Acteurs institutionnels, milieux politiques et société civile (pp. 75-87). Stuttgart: Steiner Verlag.

Veivodová, P. (2016). The Anti-EU Groups in the European Parliament. In P. Moreau and B. Wassenberg (eds.). European Integration and new Anti-Europeanism I, The 2014 European Election and the Rise of Euroscepticism in Western Europe (pp. 71-85). Stuttgart: Steiner Verlag.

Vignaux, E. (2004). Les ressorts confessionnels de l'euroscepticisme. Facteurs religieux et comportement politique dans les pays Nordiques. Nordiques, 5, 83-109.

Warlouzet, L. (2014). Dépasser la crise de l'histoire de l'intégration européenne. Politique européenne, 2, 98-122. Available at: https://doi.org/10.3917/poeu.044.0098.

Wassenberg, B. (2007). Les campagnes pour les élections européennes de 1979, en France et en Allemagne. In M. T. Bitsch, W. Loth and C. Barthel (eds.) (p. 263). Cultures politiques, opinions publiques et intégration européenne. Bruxelles: Bruylant.

(2012). Regards croisés sur la construction européenne. Diversité des coopérations et des résistances à l'Europe. Habilitation thesis. Strasbourg: University of Strasbourg.

- (2013a). History of the Council of Europe. Strasbourg: Editions of the Council of Europe.

(2013b). L'opposition à la création de la CEE au sein de l'Assemblée parlementaire du Conseil de l'Europe (1955-1957). In M. Gainar and M. Libera (eds.). Contre l'Europe? Anti-européisme, euroscepticisme et alter-européisme dans la construction européenne de 1945 à nos jours (Volume 2): Acteurs institutionnels, milieux politiques et société civile (pp. 105-127). Stuttgart: Steiner Verlag.

(ed.) (2017). Castle-talks on Cross-Border Cooperation. Fear of Integration? The Pertinence of the Border. Stuttgart: Steiner Verlag.

- (2019). Euroscepticism at the EP elections in 2014: Reflection of the Different Patterns of Opposition to the EU?. In O. Costa (ed.). The European Parliament in times of EU crisis. Dynamics and Transformations (pp. 275-299). Cham: Palgrave. Available at: https://doi.org/10.1007/978-3-319-97391-3_13.

and Schirmann, S. (2019). Political Culture and Dynamics of the European Parliament, 1979-1989, Luxemburg, European Parliament History Series. Available at: https:// www.europarl.europa.eu/thinktank/en/search.html?word=Dynamics 